\title{
REREADING NORMAL SCIENCE
}

\author{
Dimitri GINEV \\ Center for Culturology \\ University of Sofia "St. Kliment Ohridski" \\ dginev@aster.net
}

SUMMARY: This paper considers the relevance of a class of hermeneutic concepts to the philosophical reading of normal scientific research. The author opposes the view that the notion of "normal science" can only be read in socio-psychological, sociological or ethnomethodological terms. By drawing parallels between Kuhn's original reading of puzzle-solving enterprise and Gadamer's philosophical hermeneutics, a context of "Continental theories" for interpreting the dynamics of research practices is delineated. The rereading of normal science provides the opportunity for developing a hermeneutic alternative to the analytic philosophy of science.

KEY WORDS: phronesis-rationality, practical experience, hermeneutic forestructure, hidden normativity

RESUMEN: Este trabajo examina la relevancia de cierta clase de conceptos hermenéuticos para la lectura filosófica de la investigación científica normal. El autor se opone a la idea de que la noción de "ciencia normal" sólo se puede entender en términos socio-psicológicos, sociológicos o etnometodológicos. Trazando paralelos entre la lectura original kuhniana de la empresa de solución de enigmas y la hermenéutica filosófica de Gadamer, se delinea un contexto de "teorías de Europa continental" para interpretar la dinámica de las prácticas de investigación. La relectura de la ciencia normal da la oportunidad de desarrollar una alternativa hermenéutica a la filosofía analítica de la ciencia.

PALABRAS CLAVE: racionalidad-phronesis, experiencia práctica, estructuras anticipatorias hermenéuticas, normatividad escondida

1 .

Many philosophers of science have engaged during the past three decades in a thoroughgoing reevaluation of the relationship between their discipline and various ideas of Continental philosophy. The present paper is devoted also to such a reevaluation. My aim is to discuss some of the tenets of a variety of "hermeneutic philosophy of science" through a rereading of Kuhn's concept of normal science. My basic assumption is 
that Kuhn's elaborations on normal (routine) research provide a base for comparison between his historical philosophy of science and Gadamer's philosophical hermeneutics. The author of Truth and Method praises Kuhn for taking into account "a hermeneutic dimension" in his paradigmatic conception of scientific development. Furthermore, because of this dimension, he is successful in orienting philosophy of science beyond the dilemma between Kantian transcendentalism and logical empiricism.

Interestingly enough, Gadamer suggests this appraisal in a paper devoted to the question of whether the post-war intellectual climate does lead to a reduction of philosophy in toto to "theory of science" [Wissenschaftstheorie] (see Gadamer 1981, pp. 151-159). In several papers from the early 1970s he argues in favor of the negative answer. According to a main argument for this answer, it is the intrinsic development of the philosophy of science that rehabilitates practical and hermeneutic philosophizing. Kuhn's theory of science — so Gadamer's argument goes - allows the natural sciences to be aware of their limits. The hermeneutic dimension of normal scientific research is also acknowledged by Kuhn, who in the Introduction to The Essential Tension confesses that he as a physicist had to discover for himself the importance of hermeneutics. Kuhn adds to this confession: "In my case, however, the discovery of hermeneutics did more than make history seem consequential. Its most immediate and decisive effect was instead on my view of science" (Kuhn 1977, p. XIII).

To be sure, various "hermeneutic elements" are to be discovered in the post-positivist tradition of constructing models of science's cognitive structure and dynamics. In contrast to many representatives of this tradition, however, Kuhn's kind of hermeneutics of scientific research is not to be reduced to the interpretative correlations between empirical data and theoretical frameworks (in particular, between theory and experiment). Most of the post-positivist authors are predominantly preoccupied with these correlations. In their account, because of the intimate entanglement of experimental observation with 
theory's structure, there is no "neutral observation language". Moreover, all scientific languages are "always already" interpreted. The linguistic construction of both scientific observation and scientific theory is impregnated with procedures of interpretation. The thesis of theory-ladenness of observation (as it is formulated and championed in the late 1950s and 1960s by Toulmin, Achinstein, Hanson, Polanyi, Hesse, and Feyerabend) contributed to replacing both empiricist and objectivist kinds of epistemology by interpretative theories of the structure and dynamics of scientific knowledge. The post-positivist authors displayed also discontent with the strongly deductive account of scientific theory that represents it as interpretations of theoretical postulates, or, as theoretical and observational concepts, and correspondence rules relating theory to observation. There is no structural part of a scientific language (regardless how rigid are its syntax and semantics) that is not a linguistic construction. Following different versions of DuhemQuine thesis, post-positivists went to entangle the theoretical holism about meaning variance of "observational language" with epistemological views of science's historicality. Yet they looked not for an interpretative theory of scientific research, but for a reformulated (historicist and holist) epistemology that can overcome the static "rational reconstruction" of science suggested by logical positivists. What distinguishes Kuhn's conception of normal science from the mainstream of post-positivism, is the search for accounts of science's research practices that is irreducible to epistemology. The paradigm of science-as-practice as opposed to the paradigm of science-as-knowledge was initiated precisely by Kuhn's elaborations on the notion of normal science.

In reaching this conclusion, however, one has to distinguish between Kuhn's "hermeneutic dimension" and other significant hermeneutic tendencies in the philosophy of science. Thus, Kuhn is not trying to reveal a complementarity between hermeneutic prudence and epistemic rationality in the development of science, which seems to be a main concern of Stephen Toulmin's recent work as a continuation of his ear- 
lier “evolutionary ecology of science". ${ }^{1}$ Furthermore, Kuhn's interpretative conception of the routine research practices is not a hermeneutic variety of cognitive psychology. For many years, the view has gained currency that this conception is a counterpart to Polanyi's psychological hermeneutics of scientific research. Kuhn's theory of normal science has nothing to do with psychology at all. Notoriously, the accusations in psychologism stem from the debates with the critical rationalists. It was Popper's critique that attributed to "Kuhn's dogmatism" a sort of irrational psychologism. Popper believes that the psychologistic account of normal research legitimates an image of science that is a "danger to our civilization". In the mid 1970s, Alan Musgrave stressed that the only difference between Kuhn's "normal scientific puzzle-solving" and Lakatos' "work in the protective belt" is that Kuhn, "following Polanyi, uses psychological terminology, and speaks of the normal scientific community being 'committed' to its paradigm. Lakatos, on the other hand, speaks not of 'commitments' but of methodological decisions" (Musgrave 1976, p. 458).

In fact, Kuhn has never dealt with the psychological problematics of the motivation of a scientific community's members. In saying this, I should like to return to the parallel with Gadamer's philosophical hermeneutics. "Commitment to a paradigm" has not so much to do with personal (or collective) motivations as with the conservatism of normal scientific mentality. The latter cannot be elucidated in terms of the "context of discovery". "Commitment to a paradigm" is Kuhn's expression for what in philosophical hermeneutics one calls internalization of (and attachments to) the "prejudices of a tradition" (or, the "pre-judgments informed by a tradition"). Both, "commitment to a paradigm" and "tradition's prejudices" are not subjective but rather trans-subjective phenomena. Both

${ }^{1}$ In some recent papers, Toulmin champions a kind of "hermeneutic unity of science" (see, for instance, Toulmin 2002). By contrast, Kuhn strongly opposes in his late work such a view. By the beginning of 1990s he wrote that because the human sciences are interpretative-dialogical, through and through, "very little of what goes on in them at all resembles the normal puzzle-solving research of the natural sciences" (Kuhn 1991, pp. 22-23). 
of them transcend the epistemic opposition between subjective and objective. Normal scientific "dogmatism" is informed by the resistance of scientific communities to go beyond the horizon of familiar research practices. Like Gadamer's defence of the "tradition's authority", Kuhn stresses the "paradigm's authority" by following the idea of "understanding by applying". For Gadamer, "application" mediates between interpretation and understanding, creating thereby a triunion. Understanding cultural artifacts means understanding them with respect to their application either in their own historical contexts or in the present situation. (The latter case is illustrated by the "interpretative application" of law and Scripture.) For Kuhn, the idea of "interpretative application" correlates with the question of how conceptual, experimental and mathematical tools are applied in puzzle-solving enterprise of normal scientific research. For both thinkers, "understanding by applying" grounds a kind of "hermeneutic conservatism".

Despite the essential convergence in several respects between the views of both authors, an essential difference between Kuhn's historical philosophy of science and Gadamer's universal hermeneutics cannot remain unnoticed. What I have in mind is the deep discrepancy between Kuhn's incommensurability thesis and Gadamer's conception of the "fore-structure of completion" that lays the foundations of the "dialogue that we are". For Gadamer, there are no closed "theoretical worlds" since there are no horizons of cognitive work, which are deprived of a potential fusion with other horizons. Against the background of the conception of the "fusion of horizons", one cannot formulate even in the weakest form a thesis of incommensurability within Gadamer's universal hermeneutics. By implication, Kuhn's historicist relativism (as related to the incommensurability thesis) is to be dismissed from Gadamer's position of hermeneutic antirelativism.

In sum, there is a special sort of hermeneutics involved in the conception of normal science. It takes a middle position between Gadamer's universal hermeneutics and Polanyi's "cognitive hermeneutics". In order to make it explicit, one has to 
place the conception of normal science in a broader context of "Continental theories". More specifically, in what follows I am going to make use of the so-called "practice theory" and Heidegger's theory of "ontological interpretation" as a kind of phenomenological constitutional analysis. In so doing, my aim will be not only to bring to the fore the hermeneutic dimensions of Kuhn's reading of normal science, but also to demonstrate the possibility of a comprehensive hermeneutic theory of scientific research. Since the theory of discursive practices and the constitutional analysis of hermeneutic phenomenology constitute the interpretative context of the upcoming rereading, in the course of this paper I will comment on peculiarities of both theories.

\section{2 .}

As illustrations of normal scientific research Kuhn points out the constant examination of atomic and molecular spectra in the years since the birth of wave mechanics, the eighteenth-century development of Newtonian dynamics, and the development of chemical thermodynamics (see Kuhn 1977, p. 233). Two epistemic processes take place in these (to use Kuhn's expression) "normal research projects" — an adjustment of existing theory or existing observation in order to bring the two into closer agreement; and an extension of existing theory to areas that it is expected to cover. Through these processes the practitioners of normal scientific research try to elucidate topographical details on a "map whose main outlines are available in advance". This "in advance" may mean two things. First, the scientists involved in a normal scientific research know in advance the items that the domain does and does not contain. (I borrow the notion of "item" from Dudley Shapere's (1984) approach to research domains. In his account, a domain is each body of information constituted by items for which an answer to an important problem is expected. Thus, the main items of molecular genetics as a domain are the molecular structure of the gene; the central role of DNA and RNA in the production of various structural, catalytic, and regulatory proteins; decreased enzyme 
production; biosynthetic pathways; the network of chemical reactions between genes and gross phenotypic structures; and the phenomena as epistasis, pleiotropy, and the position effect which have no satisfactory explanations in terms of Mendelian genetics. Each item is characterized by a central problem, which is realized as a theoretical problem by means of a model that provides an explanatory scenario as to how the problem is to be solved.) Practitioners of normal scientific research do possess an anticipatory knowledge concerning the possible items of their domain because by adopting the domain's existing theory they are able to "see" the empirical scope of what has to be investigated. Thus considered, "in advance" is in full agreement with the theory-ladenness claim.

Yet there is also an entirely different meaning that is irreducible to the triangle "theoretical framework - background knowledge - empirical data". The main outlines of a research domain can be known in advance because of scientists' commitment to the practical experience of a given tradition. ("Experience" here is a translation of the German word Erfahrung.) In his later writings Kuhn often refers to normal science as an initiation into an unequivocal tradition of training in certain esoteric practices of doing research like experimentation, instrumentation, measurement, calibration, constructing datamodels, building and solving systems of differential equations, different kinds of calculation, applying and revising theoretical concepts and models, designing graphical representations, etc. This claim does not belong to post-positivistic epistemology. It is rather congruent with views and postures of philosophical hermeneutics (most of all, Gadamer's hermeneutics of experience). According to it, experience is not a set of cognitive procedures (guided by epistemological criteria of justification), but interrelated practices which in their historicality constitute a tradition. Likewise, Kuhn treats normal scientific research as "experience", i.e. as a transmission of discursive practices that takes the form of tradition. The participants in these practices have become "indoctrinated" by a "tradition's authority". Yet this is not an authority embodied in a corpus of doctrines. It 
is rather the experience that is handed down by a "dialogue with tradition", which "teaches" the participants to recognize the specific reality of their research domain. The experience accumulated in the tradition (and not the firm theoretical framework) informs practitioners' anticipations, orientations, and inclinations in the research process. The very tradition is not determined by an established theory. On the contrary, it is the practical experience of a tradition that "fore-structures" both the formation and the acceptance of a theory. ${ }^{2}$

Against the background of the preceding considerations I am going to differentiate between two basic readings of Kuhn's "normal science". The reading that makes use of concepts like tradition, discursive practices, experience, and so on (the "tradition-bound reading"), is a specification of the hermeneutic idea of historicality, whereas the reading that is close to the view depicted by Popper under the heading of "the myth of the framework" (framework-reading) is consonant with the theory of knowledge supported by cognitive relativists. The ambiguity in Kuhn's conception has provoked in recent years several attempts to commit both readings (in terms of postpositivistic epistemology and in accordance with the concepts of tradition and "practical experience") of the notion to two lines of a philosophical critique of science. More specifically, the discrepancy between both readings was recognized as a manifestation of the conflict between hermeneutic theory of normal scientific practices and epistemologically-centered model of sci-

${ }^{2}$ Let me note that in contemporary writings on the notion of tradition —which follow a now classical book of Edward Shils (1981) - , the view gained currency that the inherited ways of giving meaning to experience is linked to communities' collective memory. Yet constitutive of tradition is not only collective memory, but collective forgetfulness as well. The latter is to be depicted in terms of a disactivation of practices in transmitting experience. A normal scientific tradition is unconscious transmission of exemplars for resolving problems through experience in which an interplay of activation and disactivation of research practices takes place. The constellation of collective memory, collective forgetfulness, and articulation of meaning in transmitting practical experience has much to do with the notion of "historiographic narrative" which plays an important role in Kuhn's papers from the 1980s. 
entific communities" "dogmatism" and "conservatism" (see, in particular, Rouse 1987 and Ginev 2000).

According to the tradition-bound reading, normal scientific research is "always already" in a horizon of shared orientations, anticipations and inclinations, which is projected onto the totality of a community's research practices in the domain. This reading states that the decision to accept the assumptions guiding normal scientific research is already informed by a horizon as an interrelatedness of research practices and by a "tradition's authority". The rational decisions made by the members of a scientific community come into being within a projected horizon of doing research. It is this horizon within which the (individual and collective) rational choices in the research process take place. The reading of normal science in terms of a hermeneutic conception of historicality requires taking leave of many (customary) epistemological distinctions. To reiterate, whereas tradition-bound reading involves moving from practices, traditions and experience to an analysis of how science's cognitive content becomes constituted within horizons of normal research, framework-reading keeps the intention of a revival of schemecontent-epistemology.

Upholders of the tradition-bound reading like Patrick Heelan (1983) and Joseph Kockelmans (1997a, 1997b, 2002) show little sympathy for the account of the stability of research practices in terms of a paradigm articulation due to the application of general laws (and "conceptual schemata") to new cases in the domain of inquiry. Explaining normal science's stability with the deductive articulation of a paradigm would entail ignoring the historicality of scientific research. This is why attention in the tradition-bound reading is paid chiefly to the activity of solving problems (through exemplary solutions) in which past experience, present concern, and projected future form the inner temporality of scientific research. (Let me reiterate that the tradition-bound and the framework reading of normal science are not only two opposite philosophical interpretations of Kuhn's ideas, but two conflicting tendencies in Kuhn's thought. Strangely enough, from the paper "The Essential Tension: Tra- 
dition and Innovation in Scientific Research" [1959] to his final writings both tendencies were at once in a peaceful and conflicting coexistence.)

Both readings would approve the definition of normal science as a mode of doing research that uses a past achievement as a model and guide for formulating and solving problems within an established domain without bringing into question the basic theoretical and methodological assumptions of the research process. Yet they differ essentially in construing the issue of the way these assumptions are accepted by a scientific community. No doubt, the kernel of the controversy concerning Kuhn's legacy lies in the interpretation of the claim that normal scientific research is guided by a series of paradigmatic assumptions which are generally accepted by those working in a particular domain. I will call this the "acceptance-claim".

According to the framework-reading, the acceptance-claim means that due to a rational choice the members of a scientific community accept something like a conceptual scheme (cum a methodological code of doing research). Following this interpretation of the claim, one faces the model of making a rational decision within an already accepted theoretical framework. On this model, there is normal scientific research in a given domain, as long as there are shared commitments to a conceptual scheme (and a "metaphysical paradigm"), each of these commitments consisting of individual rational decisions. The interpretation in terms of rational decision-making reproduces the distinction between context of discovery and context of justification. More specifically, if we start out with the rationally accepted conceptual scheme, we will have two options of explaining normal scientific research. We can either concentrate our attention on the collective motives for accepting the conceptual scheme that provides the assumptions shared by the members of the community, or we can assess the rationality of this acceptance against the background of certain epistemological and methodological norms. The former explanation would be in terms of social psychology (and it would be relegated to the "context of discovery"), whereas the latter would be forged in the perspective of 
a certain "rational reconstruction" of the research process, i.e. it would belong to the "context of justification".

Analyzed with respect to the notion of theoretical framework, normal science is a specification (in terms of a theory of scientific change) of "scheme-content dualism". Wolfgang Stegmüller (1978), a leading exponent of this standard (epistemological) reading, explicates (in terms of Sneed's non-statement view of scientific theory) the concept by appealing to a theory-ladenness of observations. He goes on to stress that it is impossible to specify what empirical data would have to look like in order to falsify Newton's second law. The latter belongs to the basic core of classical mechanics. With respect to empirical refutability, this core has almost the same status as a tautology. The empirical content (however minimal it may be) of the basic core cannot be understood unless one accepts the theory. Normal scientific research is due to the immunity of the basic core (concerning empirical falsifications) in the process of applying the theory to systems of data. Normal science is the proliferation of intended applications of the basic core which precludes the refutation of the theory. During this proliferation a domain of systems of data (or, empirical models) takes shape. This is the "Sneedian translation" of Kuhn's puzzle-solving enterprise, which attempts to diminish the discrepancies between a paradigmatic conceptual scheme and the world.

To be sure, Kuhn often makes use of an epistemological explication akin to that advanced by Stegmüller. In The Structure of Scientific Revolutions, he admits that normal science is a kind of research, in which an established paradigm functions "by permitting the replication of examples any one of which could in principle serve to replace it" (Kuhn 1962, p. 23). According to this view, which gives rise to the standard reading, normal science is an ad infinitum process of replication of a pattern or a conceptual scheme by means of which an uninterpreted objective reality has become the "theoretical world" of a scientific community. Normal scientific research is directed to the further articulation of that world. (The determination of universal constants, the search for experiments that are necessary 
to choose among alternative lines of applying the paradigm, and the discovery of quantitative laws are the ways of such articulation discussed by Kuhn.) The underlying cognitive framework of paradigmatic achievement becomes firmly established as a framework for solving problems. Normal science offers formulations and possible solutions of these problems which do not threaten the "conceptual orthodoxy" held by the members of a domain's scientific community. As a kind of research, normal science is predicated on a cumulative intellectual advance because there is a consensus in the scientific community about cognitive values and goals, methodological norms, explanatory models, and issues like the efficacy of the techniques of investigation and the relevance of mathematical formalisms. Thus, on this reading, achieving a consensus in a scientific community is determined by the domain's (static and fixed) cognitive structure.

3 .

My claim in this section is that the tradition-bound reading of normal science has to have recourse to the so-called "practice theory". ${ }^{3}$ The basic goal of its champions (like Bourdieu, Giddens and Schatzki) is to eliminate any form of Cartesian dualism in treating the cultural dynamics of discursive practices as practices that constitute various kinds of "social worlds". Notions like "practical understanding", "habitus", "practical experience", "unconscious", "practical logic", "concernful interpretations" are construed as ingredients of the very dynamics of discursive practices, and not as characteristics of a mentality existing per se. The devaluation of consciousness as an "independent essence" that determines social life is a main concern for those who are operating with the aforementioned notions. A central issue of practice theory is the question of how discursive practices constitute "mind" (as a diversity of mentalities corresponding to the "social worlds"). In trying to entangle the tradition-bound reading of normal science with practice theory,

${ }^{3}$ On the main lines of "practice theory", see Bourdieu 1990, Giddens 1984, and Schatzki 1996. 
I will consider, in this section, a very restricted version of practice theory, known in cultural anthropology as a "theory of ritualized praxis". In the next section, I am going to take into consideration an extended version, which is, in fact, a "scientific version" of hermeneutic phenomenology.

The reading of normal science in terms of practice theory is epitomized by the attempts to equate the routine interrelatedness of practices of scientific research with the ritual repetition of doings, which preserves the status quo of a given social order. To be sure, normal scientific research is a transmission of "practical experience" (including the practical experience of constructing theoretical models) through routine activities that preserve the structure of a community. Since to a certain extent this transmission occurs unconsciously, normal science takes on the form of a "ritualized praxis". Kuhn's puzzle-solving enterprise is (like any other ritual) an activity devoid of personal commitment to the values being expressed. According to Mary Douglas (1970, p. 21), ritual is preeminently a form of communication and ritual form is a transmitter of culture. Likewise, normal science is a medium of communication, which transmits habits, skills, patterns and algorithms of solving problems, and, more generally, an ethos of practical behavior. A reading of normal scientific tradition in terms of a cultural-anthropological account of ritual displays, however, the danger of a hypostatization of certain "regimes" of discursive practices.

Vis-a-vis the present discussion, normal science as a ritual is an enterprise devoid of personal commitment to the values, norms and standards being expressed. Those who are involved in this enterprise "speak" (in a collective and unreflective manner) the normative-social order so as to have normal scientific research. But if one simply goes on to postulate that ritual is an anonymous execution of interrelated practices, then again one risks hypostatizing the social order (and the interrelatedness of practices underlying it). This is precisely what happens in the theory of ritual as a version of practice theory. In the case of normal science, it is the periodic reaffirmation of the coherence of a theoretical world through a ritual ex- 
ecution of puzzle-solving activities that exercises a solidaritymaintaining function. There is a ritual —so practice theory's argument goes - because the discursive-practical articulation of meaning within the laboratory everydayness and routine communication is based on "rigid syntax" and "restricted codes" of social-normative order which limit the ability of the community's members to transgress the "normal scientific space of possibilities". In a good Durkheimian way one starts out with (the restricted codes of) "collective representations", forgetting thereby the "situational and contextual genesis" of the particular configurations of practices. The scientific community "learns" in a collective fashion specific codes that regulate its laboratory everydayness, and through its discursive practices it "speaks" the social structure which is indispensable for having a normal scientific research. In other words, normal science as a ritual is the involvement of a scientific community in a codified (and distinguished by a "rigid syntax") everydayness of iterative practices. The hypostatization of a restricted code as a mechanism of transmission of stable configurations of practices (whose carrying out provides a periodic reaffirmation of the social-normative order) is the principal defect of this theoretical account. It is this deficiency that a reformulation of normal science in terms of hermeneutic philosophy tries to overcome. A first step in that direction would be an outline of the rationality that corresponds to a hermeneutic reading of normal science.

In The Essential Tension, Kuhn often speaks about normal science as a "tradition-bound work" guided by "exemplars" (i.e. concrete problems with their solutions which do not call into question the very tradition). Doing-research-within-a-tradition is governed by a sort of phronesis-rationality which is incompatible with the epistemic rationality that consists in normative criteria and standards of applying a theoretical framework to particular problems. Following hermeneutic philosophy, practical experience (and not epistemological norms and criteria, or "restricted codes" of ritual everydayness) constitutes the core of phronesis-rationality. Yet to stress the role of the particular and 
the "exemplars" in practical experience does not mean to get rid of general models and structures. Phronesis is rather a mediation between the general and the particular. Richard Bernstein, a prominent champion of the hermeneutic reorientation of the philosophy of science, makes in this regard the following observation: "As Aristotle stresses, and Gadamer realizes, phronesis presupposes the existence of nomoi (funded laws) in the polis of community. This is what keeps phronesis from degenerating in the mere cleverness or calculation that characterizes the deinos (the clever person). Given a community in which there is a living, shared acceptance of ethical principles and norms, then phronesis as the mediation of such universals in particular situation makes good sense" (Bernstein 1983, p. 157).

The hermeneutic notion of phronesis-rationality involves the possibility of innovations in the ongoing performance of practices. To be sure, normal science is not only a routine but an innovative interrelatedness of practices too. Innovations within normal science are generated by the changing configurations of research practices. In extreme cases, new configurations may even provoke a change of a "research domain's identity". Let me give an example in this regard. At the beginning of the 20 th century a normal scientific research in the domain of bacterial chemistry began to take shape. Routine practices of extracting, separating and examining enzymes from yeasts and bacteria were established. Champions of bacterial chemistry believed that microbes may produce valuable chemical products. Yet they pay little attention to the complex physiologies of these organisms. The decline of the domain of bacterial chemistry began when its established configurations of research practices were applied to coping with the complexity of bacterial metabolism. At that stage, the champions of bacterial chemistry failed to recognize the basic difference between reactions and products of this metabolism and laboratory reactions and products. The reaction to this failure provoked the shift from bacterial chemistry to bacterial physiology whose practitioners from the very outset managed to push beyond the limits set by the prejudices of chemical research (see Kohler 1985). 
4.

In order to avoid the hypostatization I spoke about, let me now change the perspective through placing the tradition-bound reading in the context of Heidegger's theory of "ontological interpretation". It is not my aim to enter into details of this theory. I shall make use of it only as a necessary counterpart of practice theory. Elsewhere, I called the application of hermeneutic phenomenology to issues of scientific research a kind of "cognitive existentialism" (see Ginev 2003). On this "existentialist account", the research process is "always already" projected into possibilities (of doing further research) that are situationally actualized by configurations of interrelated practices. This "projectedness" directs the research process towards the constitution of a scientific domain (see Dreyfus 1991, pp. 184208). Thanks to the sustained "pressing into possibilities", the research process (regardless of how advanced is the domain's cognitive completeness) is always open for further development. The more possibilities become actualized, the wider the horizon of new possibilities. (Thus, for instance, in the domain of nonlinear chemical reactions, normal scientific research consists in describing patterns of nonlinear dynamic systems like multiple steady states, birhythmicity, quasiperiodicity, bifurcations and so on. To solve puzzles in this domain amounts to enriching the phenomenological diversity typical to systems of chemical reactions far from equilibrium. To normal scientific research belongs also the search for systems of nonlinear differential equations that govern the different kinds of dynamic behavior. The experimental and mathematical description of a certain pattern is an actualization of a projected possibility. As a rule, a successful description provokes investigations of "deviations" from the pattern. The purpose is to discover new patterns of nonlinear dynamics and, thus, to realize new possibilities of normal scientific research.)

In the ongoing actualization of possibilities, there are always understanding and interpretation involved in the research process. These are not specific cognitive procedures, but ontological characteristics of the constitution of (experimental, instrumen- 
tal, calculative, etc.) meaning within the domain of research. On Heidegger's account, understanding is a projection of an open horizon of possibilities. Interpretation is not something external to understanding. In interpretation understanding's own possibility becomes actualized. Interpretation appropriates what is projected (understood), whereby it articulates the meaning within an interrelatedness of discursive practices. More specifically, the "understanding which interprets" and the "appropriative interpretation of what is understood" articulate the meaning "embedded" in an interrelatedness of practices that forms the "everydayness" of a given community. It is this meaning that "fore-structures" the thematic predication taking place in the formation of a research domain. The nexus "projected understanding-appropriative interpretation" is the chief idea of hermeneutic phenomenology that is to be implemented in the rereading of normal science (see also Kisiel 1976, Crease 1993, Eger 1995, 1997, Heelan 1997, 1998, Kockelmans 1985, 1993).

The interrelatedness of research practices informs an infinite set of possible ways of carrying out the research process in a scientific domain. The proliferation of particular configurations of practices within the total interrelatedness as a horizon of possibilities rests upon the nexus "understanding-interpretation". Understanding is coupled with interpretation as phronesis of the practical involvement in the domain of scientific research. Through appropriation of possibilities that are already understood, one articulates meaning of what is ready-to-hand in carrying out practices. Understanding and interpretation within the domain of everyday routine practices of doing research houses the unreflective openness towards a range of possibilities in each particular situation. Pressed forward into possibilities, the practitioners are always already in an ongoing articulation of "meaningful objects" within the research domain. Both the "theoretical objects" and the "observable research objects" are cases in point. They both "have meaning" only within a routine interrelatedness of research practices. Furthermore, both kinds of research objects come into being through actualization of projected possibilities. Thus, e.g., the realization of the 
possibility of carrying out measurements of quantities as interactions between a system (characterized by a state-vector) and a macroscopic system of instruments leads to the constitution of "observable research objects with indeterminate values for physical quantities" for which a certain statistical interpretation is indispensable. Notoriously, on such measurements qua discursive practices depends the whole enterprise of normal scientific research in quantum mechanics.

The notion of discursive practices I am employing here is predicated on an "ontological universality". It is the correlation of praxis and articulation of meaning that gives evidence of the universality of discursive practices. Phrased differently, "discursive practices" are not a special sort of practices, but the very concernful involvement within-the-world upon which all sorts of practices are grounded. By stressing this universality, however, I am not trying to equate the language-games in which forms of intersubjectivity are articulated with the pragmatic dimensions of discursiveness. My aim is rather to underline the discursive aspect of all practices that constitute scientific research, regardless of whether verbal communication is used in their execution. Identifying bacterial species, counting total cells, and determining the number of viable cells in a culture are three typical discursive practices in microbiologists' normal scientific research. By executing them, the researchers are able to correlate observed biochemical activity with the biological state of the cells. In so doing, microbiologists create a standard routine for every experiment in their domain. The three practices can be depicted as entirely "wordless doings". Yet the communicative structuration of the community of researchers supervene on the interrelations among these "non-verbal" practices.

To put it in another way, there is always in normal scientific research a discursive medium in which research practices are carried out. All "wordless doings" are also embedded in this medium. They are not beyond (what Heidegger calls) the "totality-of-meaning". It is the dynamics of the interrelatedness of practices that provides in the first place a rationale for treating practices taking place in the research process as discursive 
practices. The elaboration of a notion of discourse that is in line with the rereading of normal science hinges again on the philosophical problem of the universality of understanding and interpretation. As I pointed out, the articulation of meaning within the "world" of a routine practices fore-structures thematic predication of the objects constituted by these practices. In other words, thematic predication presupposes the nexus of understanding and interpretation as its own "hermeneutic forestructure". If discourse is regarded as a medium of interrelated practices and as a totality of meaning of the very interrelatedness, then it serves the function of such a hermeneutic forestructure. Discourse as a medium promotes a kind of "feedback loops" between contexts of social structuration (in particular, the structuration of a normal scientific community) and configurations of research practices.

5 .

There is another aspect of the correlations between discourse and practice which deserves special attention. What I have in mind is the hidden normativity embedded in the interrelatedness of normal scientific practices (see Ginev 1999). The appropriative interpretation of what is already understood within the practical everydayness implies also an intrinsic normative regulation of what is going on in the everyday routine. To make use of a metaphor implemented by the champions of practice theory, there is a kind of "orchestration" of discursive practices underlying the teleoactive order of normal scientific everydayness. The interrelatedness of research practices houses the implicit normative base of this order. Theodore Schatzki makes it clear that unlike explicit rules, the orders constituting an everyday routine "need not be spelled out and explicitly enjoined in formulations, although formulation does sometimes occur, especially (but not only) in learning situations, in the face of nonstandard doings and sayings" (Schatzki 1996, p. 100). The hidden normativity instituted by routine discursive practices is a central issue for thinkers like Giddens and Bourdieu. 
In normal scientific research, hidden normativity comes to the surface as a "mutual normalization" of practices. Routine discursive practices promote and constrain each other in the research process. Each situation of this process is a configuration of discursive practices. Thus, in studying enzyme adaptation as an item of normal scientific research in biochemistry the "mutual normalization" includes experiments with inducers of such adaptation, specifying concepts of enzymology and biochemistry with respect to issues of bacterial metabolism, isolating strains of microbes, calculating the quantitative effects of the activity of hydrogen-activating enzymes, repeating experiments with anaerobic fermentation, designing possible experiments with systems of lactose fermentation, biochemical identifying of new enzymes, forging "ad hoc bridges" between biochemistry and bacterial physiology by correlating enzyme activity with viable cells, improving techniques for counting total and viable cells, and experimenting with bacteria that synthesize new enzymes which are highly selective in their recognition of the amino-acids.

In the hidden normativity of the mutual normalization of normal scientific practices, one has distinguished the anticipation of possible configurations of practices (fore-having), the expectation of cognitive results (fore-sight), and the orientation towards a possible outcome of a given situation (fore-conception). These three moments of the hermeneutic fore-structure "normalize" and regulate "from within" the research process. Forehaving, fore-sight, and fore-conception are (from the viewpoint of hermeneutic phenomenology) the three "proto-normative operators" of normal scientific research. To say that in each situation of this research there are (conceptual, mathematical, and instrumental) tools appropriate for the actual purposes means in the first place that these tools do not create breakdowns in the interrelatedness of practices, or that they do not violate the existing hermeneutic fore-structure. The appearance of anomalies, disturbances, and breakdowns in normal research poses questions that require the practitioners to make explicit certain implicit normative conditions residing in the interrelated- 
ness of practices. It is my contention that the transformation of the hidden normativity (of fore-having, fore-sight, and foreconception) into explicit normativity runs in accordance with the constitution of research objects in the domain. The hidden normativity is the unarticulated web of expectations, anticipations, and orientations underlying a regime of changing configurations of research practices. It is not a regime planned in advance. Once a given practice is well learned, its carrying out is fitted into a configuration. Being involved in such a configuration, the practice is accomplished with little planning how to avoid the disturbances in the normal scientific everydayness. It is the mutual normalization of research practices that allows the practitioners to avoid disturbances and breakdowns. Each normal scientific practice defines implicit normative conditions of appropriateness and is "normalized" by the other practices. The research practices keep score of "normative places" within their interrelatedness. A particular practice is appropriate if it does not violate the "scorekeeping" in the research process, or, in another formulation, if it does not cause "breakdowns" in a given configuration.

Furthermore, the hidden normativity can be defined by the situational compatibility of research practices in a "referential whole". The latter is the background upon which practices can have a point. Hidden normativity is attached to the function of "in-order-to" in carrying out a practice in a referential whole. Each practice must fit into such a whole. In another formulation, each particular practice of scientific research does make sense only within a self-regulating and self-normalizing interrelatedness of practices. The question of when an experiment is to be repeated, and the question of how the experiments end are cases in point. Several studies reveal the regulative and normalizing functions of a referential whole of practices concerning the design of various kinds of scientific experimentation. Thus, Franklin and Howson (1984) are successful in demonstrating that a verifying experiment which is identical to the original one cannot support it. Yet very often what makes a new experiment truly non-identical is not the procedure of experimentation and 
the experimental design but the new configurations of practices in which it takes place. This is why Collins (1984), in stressing the inapplicability of Franklin and Howson's argument, puts more emphasis on the question of when scientists do feel the need to vary their experiments deliberately. The need depends on the whole regime of research practices. In controversial domains where discrepancies between lines of research come into play variation in experimental design is not highly valued.

It is the regime of practices that suggests the know-how of normal scientific research. The participants of microbiological research "know how" to cope with different situations in the laboratory. They know how to design experiments and how to vary the conditions (e.g., acidity, nutrients, age of culture, and aeration) of experimentation. Furthermore, they know what is appropriate to do in each situation without distancing themselves from their "absorption" in what they are doing. The know-how is a "pre-predicative knowledge" since it is assigned not to an epistemic attitude, but to the very "concernful" involvement in the regime of practices. In this regard, the knowhow is generated directly by the interrelated practices. It is the regime of practices that "decides" what kind of experiments are necessary in order to explore, say, the systems of lactose fermentation through enzyme chemistry. It is again this regime that "selects" relevant experiments as a systematic working out of theoretical ideas regarding the patterns of enzyme adaptation. Only under special conditions can the participants in normal microbiological research cease to be "absorbed" in the regime of practices, and come to take a reflective stance towards their skillful coping with the laboratory equipment. Under such conditions, microbiologists need not only "unreflective interpretative understanding" ("know-how" for their skillful coping with the situations of normal scientific research), but a "selfreflective knowledge" about the meaning of their routine activities. Such knowledge can be obtained in different theoretical frameworks - technology of the experimental instruments, molecular biology, biochemistry, or even philosophy of biology. The role of the self-reflective stance is to give back the research 
community's capability of sustaining the integrity of practices as a "situationally changing referential whole".

To sum up, the rereading of normal science in terms of practice theory and hermeneutico-phenomenological constitutional analysis poses several new issues which, in my view, are of significant philosophical interest. In this paper, I concentrated my attention on three of them. First, the issue of how the "ontological unity" of understanding and interpretation "fore-structures" the constitution of "meaningful objects" in a scientific domain. Second, the issue of the "ontological priority" of the projected possibilities over the epistemic cut between knowing subject and objective reality in the process of constitution of research objects (and cognitive content) in a scientific domain. And finally, the issue of the "hidden normativity" embedded in the interrelatedness of research practices that makes normal science possible. Since the late $1960 \mathrm{~s}$, the three issues take a prominent place in the work of growing number of authors who are engaged in developing a full-fledged "hermeneutic alternative" to the analytical philosophy of science.

\section{REFERENCES}

Babich, B. (ed.), 2002, Hermeneutic Philosophy of Science, Van Gogh's Eyes, and God: Essays in Honor of Patrick A. Heelan, Kluwer, Dordrecht (Boston Studies in the Philosophy of Science, 225).

Bernstein, R., 1983, Beyond Objectivism and Relativism, University of Pennsylvania Press, Philadelphia.

Bourdieu, P., 1990, The Logic of Practice, Standford University Press, Standford.

Collins, H., 1984, "When Do Scientists Prefer to Vary Their Experiments?", Studies in History and Philosophy of Science, vol. 15, pp. 169-174.

Crease, R., 1993, The Play of Nature: Experimentation as Performance, Indiana University Press, Bloomington.

Douglas, M., 1970, Natural Symbols: Explorations in Cosmology, Pantheon Books, New York. 
Dreyfus, H., 1991, Being-in-the-World (A Commentary on Heidegger's Being and Time, Division I), The MIT Press, Cambridge/London.

Eger, M., 1997, "Achievements of the Hermeneutic-Phenomenological Approach to Natural Science", Man and World, vol. 30, pp. 351367.

— 1995, "Alternative Interpretations, History and Experiment", Science and Education, vol. 4, pp. 173-188.

Franklin, A. and C. Howson, 1984, "Why Scientists Prefer to Vary Their Experiments?", Studies in History and Philosophy of Science, vol. 15, pp. 47-63.

Gadamer, H.-G., 1981, Reason in the Age of Science, trans. Frederick G. Lawrence, The MIT Press, Cambridge/London.

Giddens, A., 1984, The Constitution of Society, University of California Press, Berkeley.

Ginev, D., 2003, "How to Be Simultaneously an Antiessentialist and a Defender of Science's Cognitive Specificity", in D. Ginev (ed.), Bulgarian Studies in the Philosophy of Science, pp. 187-206.

— 2000, Critique of Epistemological Reason, Bulgarian Academic Monographs, vol. 5, Academic Press, Sofia.

— 1999, "On the Hermeneutic Alternative to Normative Naturalism", Theoria, vol. 14, pp. 291-301.

Ginev, D. and R. Cohen (eds.), 1997, Issues and Images in the Philosophy of Science. Scientific and Philosophical Essays for Azaria Polikarov, Kluwer, Dordrecht/Boston (Boston Studies in the Philosophy of Science, 192).

Heelan, P., 1998, "The Scope of Hermeneutics in Natural Science", Studies in History and Philosophy of Science, vol. 29, pp. 273298.

, 1997, "Context, Hermeneutics, and Ontology in the Experimental Sciences", in D. Ginev and R. Cohen 1997, pp. 107-126.

__ 1983, "Natural Science as a Hermeneutic of Instrumentation", Philosophy of Science, vol. 50, pp. 181-204.

Kisiel, T., 1976, "Hermeneutic Models for Natural Science", Phänomenologische Forschungen, vol. 2, pp. 181-191.

Kockelmans, J., 2002, “On the Interpretive Nature of Hertz's Mechanics", in B. Babich 2002, pp. 97-116.

—_ 1997a, "Hermeneutic vs. Empiricist Philosophy of Science", in D. Ginev and R.S. Cohen 1997, pp. 191-216.

—_ 1997b, "My Journey into Hermeneutic Phenomenology of the Natural Sciences", Divinatio, vol. 5, pp. 95-112. 
Kockelmans, J., 1993, Ideas for a Hermeneutic Phenomenology of the Natural Sciences, Kluwer, Dordrecht/Boston/London.

- 1985, Heidegger and Science, University Press of America, Washington.

Kohler, 1985, "Innovation in Normal Science: Bacterial Physiology", Isis, vol. 76, pp. 162-181.

Kuhn, Thomas, 1991, "The Natural and the Human Sciences", in David Hiley, James Bohman, and Richard Shusterman (eds.), The Interpretive Turn, Cornell University Press, Ithaca/London.

—_, 1977, The Essential Tension, The University of Chicago Press, Chicago.

— 1962, The Structure of Scientific Revolutions, The University of Chicago Press, Chicago.

Musgrave, A., 1976, "Method or Madness", in R.S. Cohen, P.K. Feyerabend, and M.W. Wartofsky, Essays in Memory of Imre Lakatos, Reidel, Dordrecht (Boston Studies in the Philosophy of Science, 39), pp. 457-492.

Rouse, Joseph, 1987, Knowledge and Power (The Political Philosophy of Science), Cornell University Press, Ithaca/London.

Schatzki, T.R., 1996, Social Practices (A Wittgensteinian Approach to Human Activity and the Social), Cambridge University Press, Cambridge.

Shapere, D., 1984, Reason and the Search of Knowledge, Reidel, Dordrecht.

Shils, Edward, 1981, Tradition, Faber and Faber, London.

Stegmüller, Wolfgang, 1978, "A Combined Approach to the Dynamics of Theories", in G. Radnitzky and G. Andersson (eds.), Progress and Rationality in Science, Reidel, Dordrecht (Boston Studies in the Philosophy of Science, 58).

Toulmin, S., 2002, "The Hermeneutics of the Natural Sciences", in B. Babich 2002, pp. 25-30.

Received August 12, 2003; revised February 10, 2004; accepted March 31, 2004. 